Article

\title{
Analysis of the Scientific Evolution of the Circular Economy Applied to Construction and Demolition Waste
}

\author{
Carmen Díaz-López ${ }^{1}$ (D) Alessandra Bonoli ${ }^{2}$, María Martín-Morales ${ }^{3}$ and Montserrat Zamorano ${ }^{1, *(D)}$ \\ 1 Department of Civil Engineering, ETS Ingeniería de Caminos, Canales y Puertos, Campus Fuentenueva s/n, \\ University of Granada, 18071 Granada, Spain; carmendiaz@ugr.es \\ 2 Department of Civil, Chemical, Environmental and Materials Engineering, University of Bologna, \\ 40131 Bologna, Italy; alessandra.bonoli@unibo.it \\ 3 Department of Building Construction, ETS Ingeniería de Edificación, University of Granada, \\ Severo Ochoa s/n, 18071 Granada, Spain; mariam@ugr.es \\ * Correspondence: zamorano@ugr.es
}

check for

updates

Citation: Díaz-López, C.; Bonoli, A.; Martín-Morales, M.; Zamorano, M. Analysis of the Scientific Evolution of the Circular Economy Applied to Construction and Demolition Waste. Sustainability 2021, 13, 9416 . https://doi.org/10.3390/su13169416

\section{Academic Editors:}

Valentín Molina-Moreno and Juan Victor Meseguer Sánchez

Received: 29 July 2021

Accepted: 19 August 2021

Published: 22 August 2021

Publisher's Note: MDPI stays neutral with regard to jurisdictional claims in published maps and institutional affiliations.

Copyright: (c) 2021 by the authors. Licensee MDPI, Basel, Switzerland. This article is an open access article distributed under the terms and conditions of the Creative Commons Attribution (CC BY) license (https:/ / creativecommons.org/licenses/by/ $4.0 /)$.

\begin{abstract}
The circular economy (CE) concept applied to construction and demolition waste (CDW) is a developing field of research that entails a large amount of complex and disjointed information; thus, a comprehensive review of scientific contributions could provide a completed perspective. This article aims to analyse the existing knowledge of CE research applied to CDW, using a double integrated analysis, a systematic literature review and a bibliometric analysis. For this purpose, Science Mapping Analysis Tool (SciMAT), a software for the analysis of performance indicators and visualisations of scientific maps, has been used, which offers a complete approach to the field and evaluates the most cited and productive authors and subject areas related to this discipline. The results obtained from the 1440 bibliographic records from 1993 to 2020 show a still-developing scientific field, evolving from concerns about economic aspects to the most recent progresses in the evaluation of sustainable deconstruction. This work will contribute to the existing body of knowledge by establishing connections, mapping networks of researchers and recommending new trends.
\end{abstract}

Keywords: buildings; closed loop; SciMAT; sustainability; economic aspect; CDW

\section{Introduction}

Consumption of natural resources could triple by 2050 [1,2]. This is due to the exponential growth of the world's population, changing family structures, existing demand for households and services and the construction industry, among other sectors. Without urgent action, global waste will increase by $70 \%$ over current levels by 2050 [3-6]. Construction waste produced on a typical construction site is estimated to be as much as $30 \%$ of the total weight of building materials delivered to a building site. In the United States, around 170 million tonnes of construction and demolition waste was generated during 2003 , of which $48 \%$ was estimated to be recovered [7]. In this context, many countries are introducing strict environmental policies and regulations to protect fragile ecosystems [8], making it more difficult and expensive to extract and use specific resources [9]. Thus, in the construction sector, Level(s) has emerged [10-13]. Level(s) is an information framework proposed by the European Union and developed by the Joint Research Centre for sustainable buildings. It aims to unite the entire sector value chain around a common European language for better building performance. The aim is to have an increasingly resilient building stock within the circular economy framework (CE).

The concept of CE is a sustainable development strategy, which through a regenerative model, improves the efficiency of materials and energy use and reduces waste and emissions [10]. The concept of CE has deep-rooted origins, and it is not easy to recognise a specific date or a single author [11-15]. Nevertheless, some practical examples applied to economic systems and industrial processes have been implemented during the late 1970s, 
led by a small number of academics, intellectual leaders and businesses. With the CE comes a paradigm shift from the existing linear economy model of "take-make-consume-dispose" to a more sustainable model of "take-make-consume-reuse-recycle" [16]. The circular economy is based on the three following fundamental principles, each of which addresses several of the resource and system challenges facing industrial economies [17-19]:

- 1 : Conserve and increase the natural capital by saving finite resources and stabilising renewable resources' fluxes.

- 2: Optimise resources efficiency always, furnishing materials, components and products at their maximum value and performance levels, in both technical and biological cycles.

- 3: Promote system efficiency by identifying and eliminating negative externalities from the design.

Specifically, CE applied to buildings seeks to maintain building components and resources at their highest intrinsic value for as long as possible. Building components are kept in a continuous cycle of use, reuse, repair and recycling. It involves reducing waste and carbon footprint and preventing CO2 emissions [20]. As an example, the ICEhouse is an experimental prototype built in January 2016 for the attendees of the annual meeting of the World Economic Forum in Davos (Switzerland), with the aim of discussing the future of innovation in the circular economy. Due to its recent emergence and the complexity of the multiple disciplines involved, the concept of $C E$ applied to CDW is a broad, complex and fragmented field of research. As a result, it is impossible to obtain a single starting point from which to access this topic because of the huge number of different subjects and approaches. Furthermore, not having a broad overview of the research area or the evolution of issues in the field makes it difficult to obtain valuable and unbiased information for future research. Therefore, there is a need for comprehensive reviews that facilitate the integration of these contributions and provide a critical perspective.

The bibliometric analysis provides objective criteria to assess the products of researchers [21] and a macroscopic view of a large amount of scholarly literature [22]. Alan Pritchard introduced the concept of bibliometric analysis in 1969. However, a bibliographic study in a particular field dates back to the 19th century [23]. There are two main methods in bibliometric research: performance analysis and scientific mapping. While performance analysis aims to assess the impact of citations on the scientific output of different scientific agents, scientific mapping shows the structure of conceptual, social and intellectual scientific research and its evolution and dynamic aspects [24]. These methods provide a spatial representation of how disciplines, fields, specialisations and individual papers or authors relate to each other [25], examining bibliographic material from an objective and quantitative perspective [26].

For all the above, this article aims to analyse the existing knowledge of $\mathrm{CE}$ research applied to CDW, using a double integrated analysis, a systematic literature review (SRL) and a bibliometric analysis. The SRL establishes a methodological approach that compiles all evidence based on pre-specified eligibility criteria [27] and the double integrated analysis is a performance analysis and a scientific mapping. The performance analysis assesses the citation impact of the scientific output, and the science mapping shows the conceptual, social or intellectual structure of the research and its evolution and dynamic aspects.

The following specific objectives were established to meet this objective: (i) a quantitative analysis based on a SLR and (ii) a qualitative review based on performance analysis and science mapping. This research would like to give a contribution to the actual wealth of knowledge by highlighting and assessing trends and patterns in CE research applied to CDW, establishing its research themes, mapping networks of researchers and finally recommending areas for future studies.

\section{Materials and Methods}

A double integrated analysis was carried out to achieve the objectives of this study (Figure 1). This double analysis consists of the following phases: (i) a SRL of biblio- 
graphic records of CE applied to CDWs and (ii) a bibliometric evaluation of the identified documents. Each of these phases is described in detail in the following sections.

\section{PHASE I SYSTEMATIC LITERATURE REVIEW (SRL)}

(i). Planning and formulation of the problem

(ii). Selection of the database (s), keywords and search string.

(iii). Selection of the literature

PRISMA flowchart guidelines

(iv). Identification of periods

\section{PHASE II BIBLIOMETRIC ANALYSIS}

\section{a performance analysis + scientific mapping}

\section{Application of SciMAT}

I. Research themes detection

II. Grouping of keywords

III. Creation of two-dimensional strategic diagrams

IV. Detention of the thematic networks

V. Detention of conceptual links between research themes

VI. Contribution of research themes to the field of research (a) STRATEGIC DIAGRAM

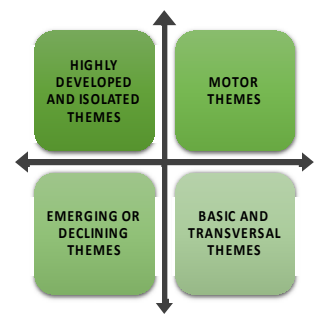

(c) OVERLAY GRAPH

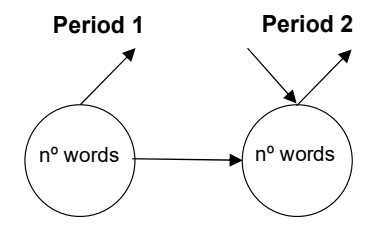

(b) THEMATIC NETWORKS

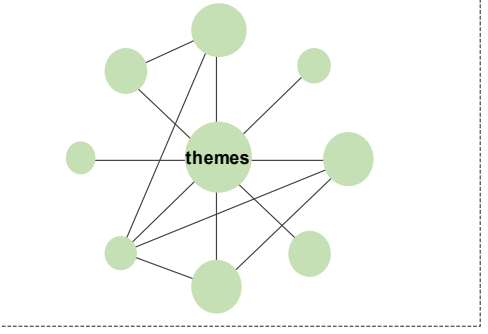

(d) EVOLUTION MAP

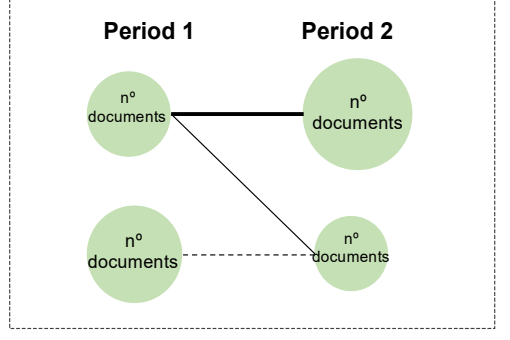

Figure 1. Materials and methods and example of a strategic diagram (a); thematic networks (b); overlay graph (c); and evolution map (d).

\subsection{Systematic Literature Review}

The SRL establishes a methodological approach that compiles all evidence based on pre-specified eligibility criteria [27]. This methodology identifies gaps, minimises research bias and provides reliable results from which judgement and conclusions can be derived [28]. SRL follows a protocol that defines the search string, strategy, exclusion criteria and methods to extract data by synthesising the results [29]. Thus, many authors have implemented SLR in their research, by developing several phases useful to perform a replicable, scientific and transparent research process [30-35]. In this article, SLR is based on the guidelines contained in Kitchenham et al. [36] (Figure 1), which are collected in the following stages: 
(i) Planning and Formulation of the Problem. In this first stage, the research questions are defined based on the objectives set, the exclusion criteria of the relevant bibliographic records and the definition of the expected results.

(ii) Selection of the database(s), keywords and search string. In this stage, the bibliographic database(s), keywords and search string are identified. Determining the keywords and a suitable search string is fundamental. The number of keywords should be large enough not to restrict the number of studies and specific enough to include only papers related to the topic.

(iii) Selection of the literature. The literature is searched, and relevant papers are selected according to the guidelines of the PRISMA flowchart [37]. Relevant documents are those that contain the necessary data to address the research objectives.

(iv) Identification of periods. Finally, periods are identified. The periods are established according to the number of relevant documents identified, the main items and the research field's turning points.

\subsection{Bibliometric Analysis: Science Mapping and Performance Analysis}

Once the SRL has been applied, a bibliometric analysis is carried out in this second phase. In this work, SciMAT v1.1.04 (Science Mapping Analysis Software Tool) was used to perform the bibliometric analysis. SciMAT is based on the analysis of common words [38] and the h-index [39]. The h-index of a researcher measures the quality of his research based on the number of his articles in scientific journals and the citations received [40]. The h-index was defined by Hirsch [40] as "A scientist has index $h$ if $h$ of his or her Np papers have at least $h$ citations each and the other $(\mathrm{Np}-\mathrm{h})$ papers have $\leq \mathrm{h}$ citations each". SciMAT incorporates methods, algorithms and measurements for all the general scientific mapping workflow steps, from pre-processing to visualisation of scientific mapping results [41,42]. Web of Science (WoS) and SCOPUS databases were used in this software. This software has been successfully applied in many areas, such as building, urban planning, waste management and IT [43-53]. This tool establishes the following stages:

1. Detention research themes and creation of two-dimensional strategic diagrams. First, the tool generates the equivalence index to detect the research themes [54]. Then, SciMAT uses the single-centre algorithm [55] to detect the most relevant topics. Then, a strategic diagram is generated per set period. The diagrams are based on centrality and density [56]. Centrality is the degree of interaction of a research topic with other research topics. Density measures the internal cohesion of all links between keywords describing the topic and gives an idea of the level of development of that topic $[57,58]$. The diagrams are thus divided into four quadrants that capture the following four types of research topics:

(a) Motor themes. They are in the upper right quadrant. Themes that are well developed and important in the scientific field. Themes essential to building the research area. They have a strong centrality and high density.

(b) Highly developed and isolated themes. They are in the upper left quadrant. Themes that are highly developed internally but isolated from the rest of the themes. These are specialised themes in peripheral areas of the research field.

(c) Emerging or declining themes. In the lower-left quadrant, themes that lack development and relevance. These themes can evolve and position themselves as relevant themes or disappear. It will be reflected in the following period. Basic and transversal themes. In the lower right quadrant. Themes are essential to the scientific field but are not yet well developed.

2. Detention of the thematic networks. The relationship of each theme in the strategy diagrams to the keywords and their interconnections are shown. Each thematic network is labelled with the name of the most significant keyword of the theme. Figure $1 \mathrm{~b}$ shows an example of a thematic network: many keywords relate to each other, the rings' magnitude corresponds to the number of documents related to each 
keyword and the thickness of the link between two circles is proportional to the equivalence index.

3. Detention of conceptual links between research themes. The inclusion index [59] detects conceptual links between research themes in different periods. The strength of association between themes is also detected. The following two types of graphs are used for their representation:

(a) Overlay graph. The number of words is represented by the horizontal arrow the number of words distributed in the two periods. The input arrow is related to Period 2's new words, while the outgoing one reflects disappeared words in Period 2.

(b) Thematic evolution map. The bold lines connect subjects with the major element. The dotted outline highlight themes connected to not fundamental items. The boundary dimension is congruent to the Inclusion Index, while the balls size corresponds to the number of publications.

4. Performance analysis. The relative contribution of research topics to the entire research field is measured quantitatively and qualitatively and used to establish the most prominent, productive and high-impact subfields using bibliometric indicators, such as the number of published papers and citations and different types of h-indexes.

\section{Results}

Once the steps of the previous section have been applied, the results are analysed in Figures 2-6 and Tables 1-5.

\subsection{Systematic Literature Review}

This section presents the results obtained by applying the SLR methodology. It includes the definition of the research questions, the search process and the definition of the PRISMA flowchart (Figure 2).

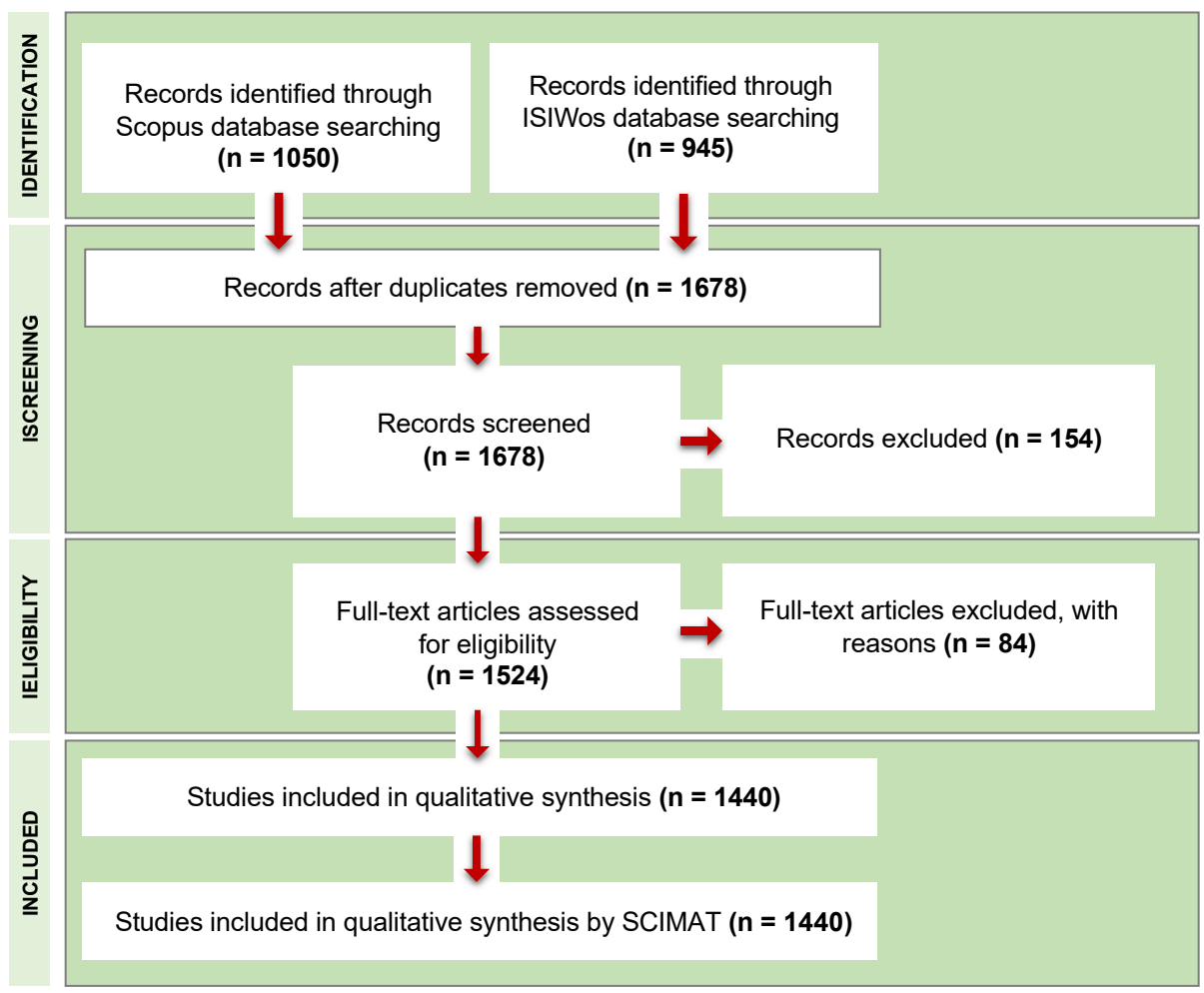

Figure 2. PRISMA flowchart. 


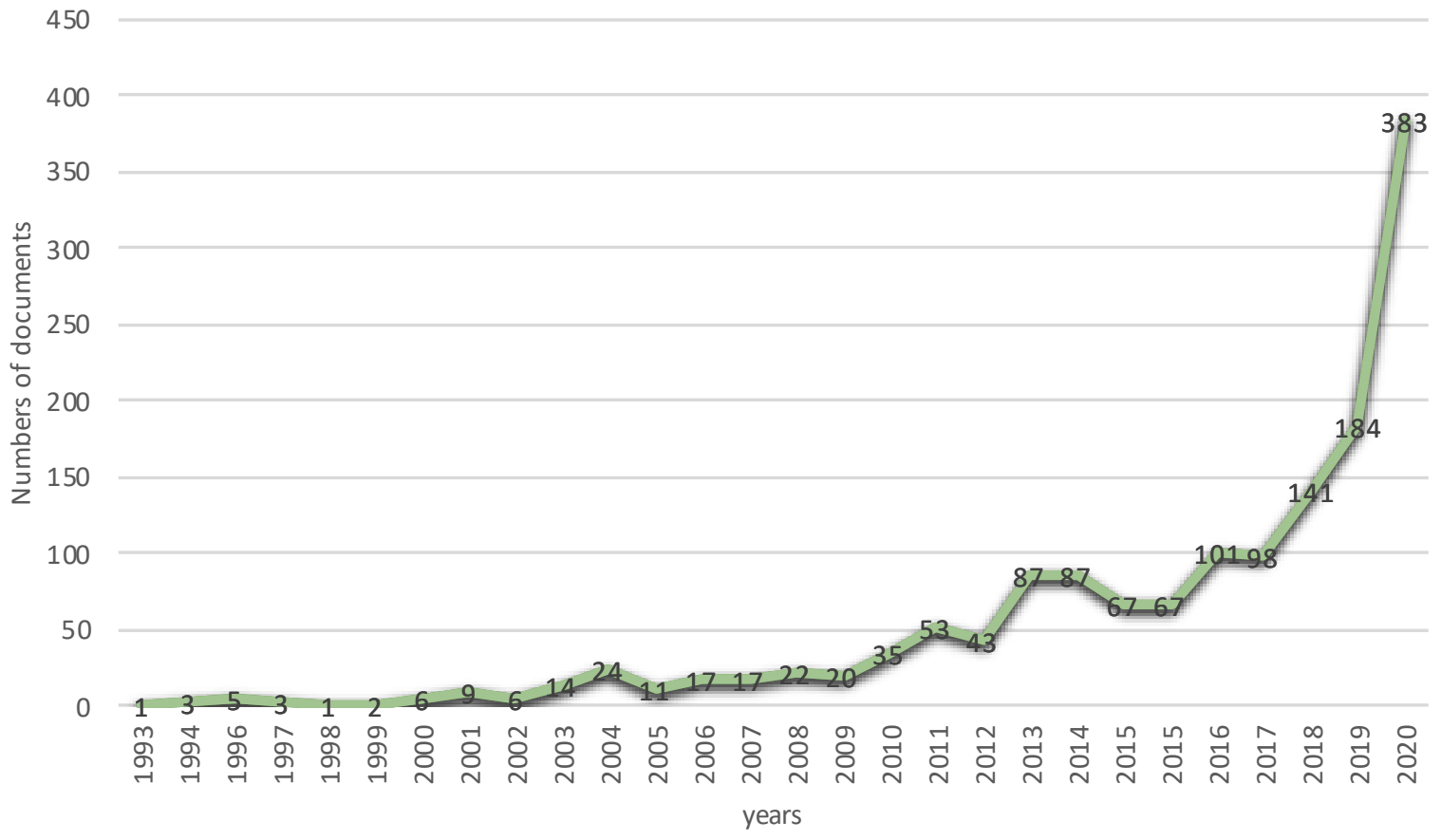

Figure 3. Documents per year.

\subsubsection{Planning and Problem Formulation}

The paper's main objective is to analyse the existing knowledge of the research field of $C E$ applied to CDW. Therefore, the following research questions (RQ) were determined based on the objectives of this work.

RQ1: What is the status of this field of study?

RQ2: What are the key concepts that define the field of research?

RQ3: What issues is the field of research evolving towards?

RQ4: What are the most relevant issues and turning points in the field of research?

RQ5: What are the most critical issues in the research field?

RQ6: What are the limitations of current research?

RQ7: What are the most influential works in the research field?

RQ8: Who are the most prolific authors in the research field?

\subsubsection{Selection of the Database(s), Keywords and Search String}

In terms of database selection, Web of Science (WoS) and SCOPUS databases were selected in this study. These databases have many high-impact international scientific and technical publications from all disciplines.

In terms of keywords, this review addressed the evolution of two main themes, EC and CDW. It is, therefore, essential that the keywords capture both themes from their origins. Notably, the topic of CE creates controversy among researchers [60-62] because of its recent development, different definitions and different ways of naming the same topic. According to Blomsma and Brenna [63], the CE theme is based on conventional thinking and has its basis in other themes. Lieder and Rashid [64] point out that there are several possibilities for defining CE. Therefore, for the CE theme to be picked up by the keywords, the inclusion of these base themes of the CE theme has been determined according to: (a) the study carried out by Kirchherr et al. [57], where 114 definitions for CE were conceptualised; (b) the topics with the exact definition of CE; and (c) those topics from which the term CE emanates. The following keywords were established for each of the themes (Table 1).

Finally, an advanced search was carried out in ISI WOS and SCOPUS using keywords from Table 1. Two search strings were used, one for each database. Thus, for 
Scopus, the search performed was: (TITLE-ABS-KEY ("CONSTRUCTION AND DEMOLITION WASTE") AND TITLE-ABS-KEY ("CIRCULAR ECONOMY") OR TITLE-ABSKEY ( “3RD PRINCIPLE”) OR TITLE-ABS-KEY (“CLOSED LOOP”) OR TITLE-ABS-KEY ("CRADLE TO CRADLE") OR TITLE-ABS-KEY ("INDUSTRIAL ECOLOGY") OR TITLEABS-KEY ("INDUSTRIAL ECOLOGY") OR TITLE- ABS-KEY ("GREEN ECONOMY") OR TITLE-ABS-KEY ("INDUSTRIAL SYMBIOSIS") OR TITLE-ABS-KEY ("CLOSING THE LOOP”) OR TITLE-ABS-KEY (“DOWNCYCLING") OR TITLE-ABS-KEY ("RECYCL") OR TITLE-ABS-KEY ("REUS*") OR TITLE-ABS-KEY ("REDUC")). For ISIWos, the search was THEME: ("CONSTRUCTION AND DEMOLITION WASTE") AND THEME: ("CIRCULAR ECONOMY" OR "CRADLE TO CRADLE" OR “3RD PRINCIPLE" OR "INDUSTRIAL ECOLOGY" OR "GREEN ECONOMY" OR "INDUSTRIAL SYMBIOSIS" OR “CLOSED LOOP" OR "CLOSING THE LOOP" OR "DOWNCYCLING" OR "RECYCL" OR "REUS*" OR “REDUC*").

(a) Period 1 (1993 - 2008)

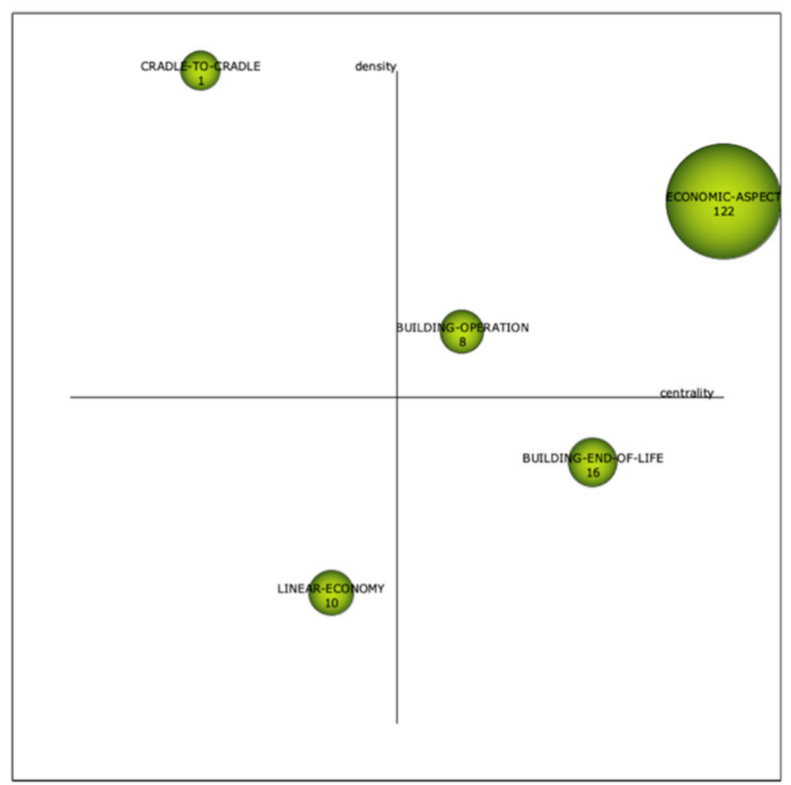

(b) Period 2 (2009 - 2015)

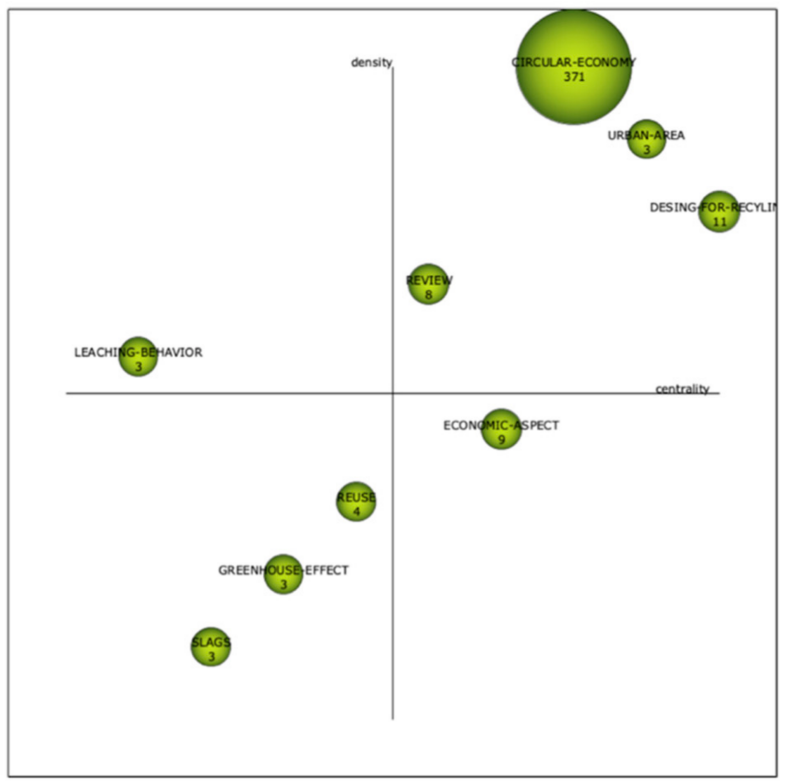

(c) Period 3 (2009 - 2020)

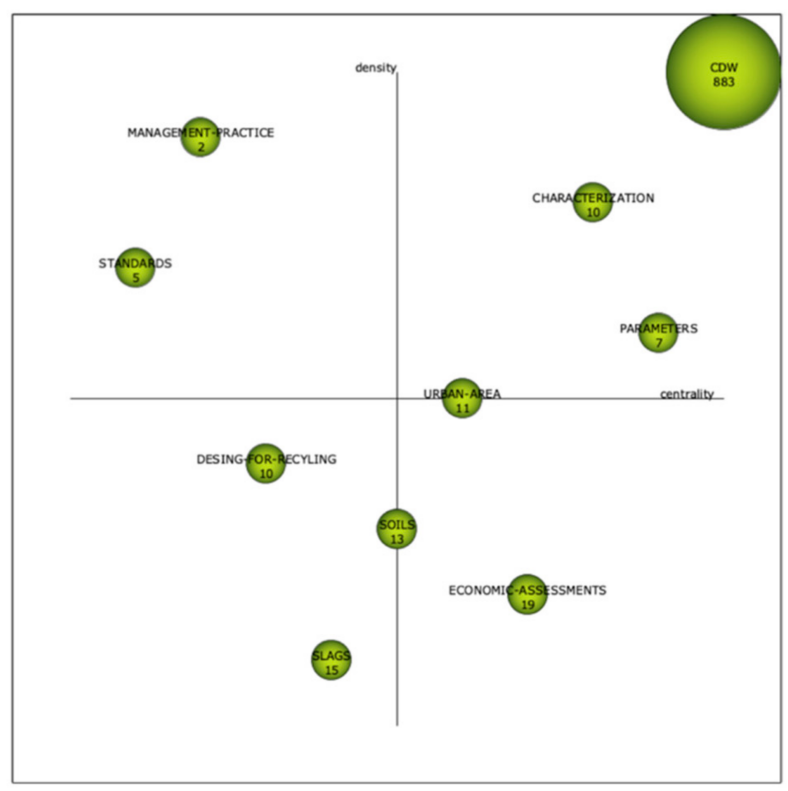

Figure 4. Strategic diagrams by (a) period 1, (b) period 2, (c) period 3. 
(a) Thematic networks by period 1 (1993 - 2008)

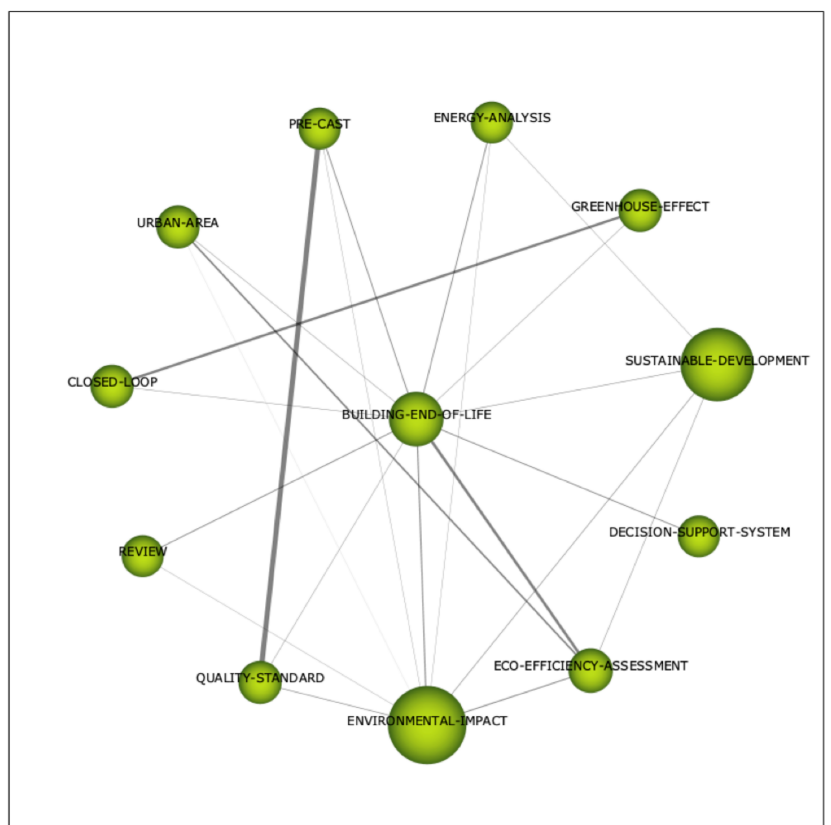

(b) Thematic networks by period 2 (2009 - 2015)

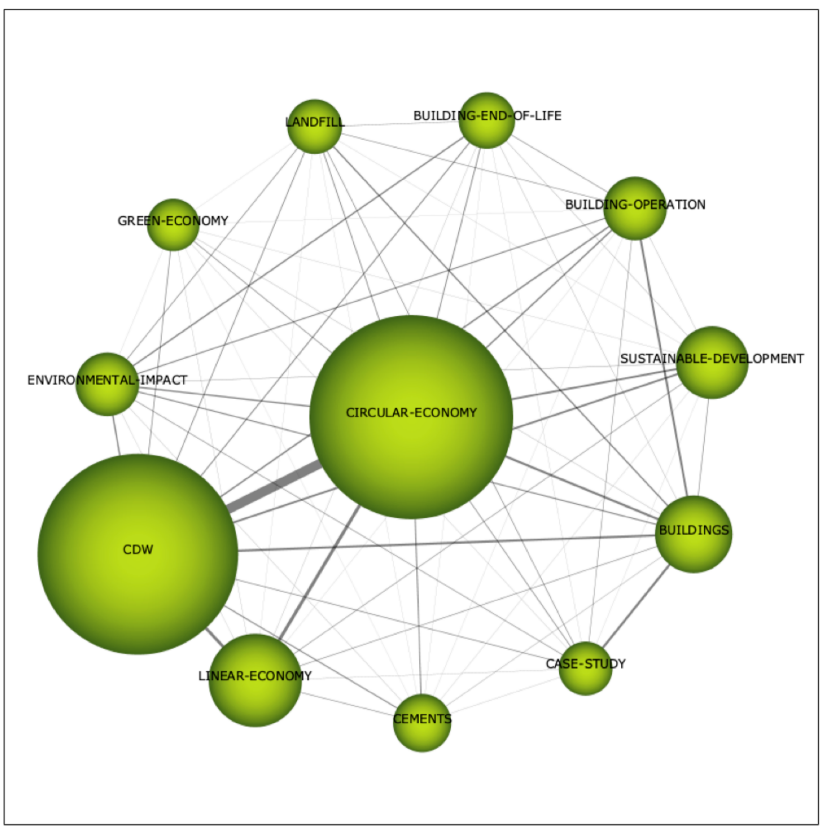

(c) Thematic networks by period 3 (2009 - 2020)

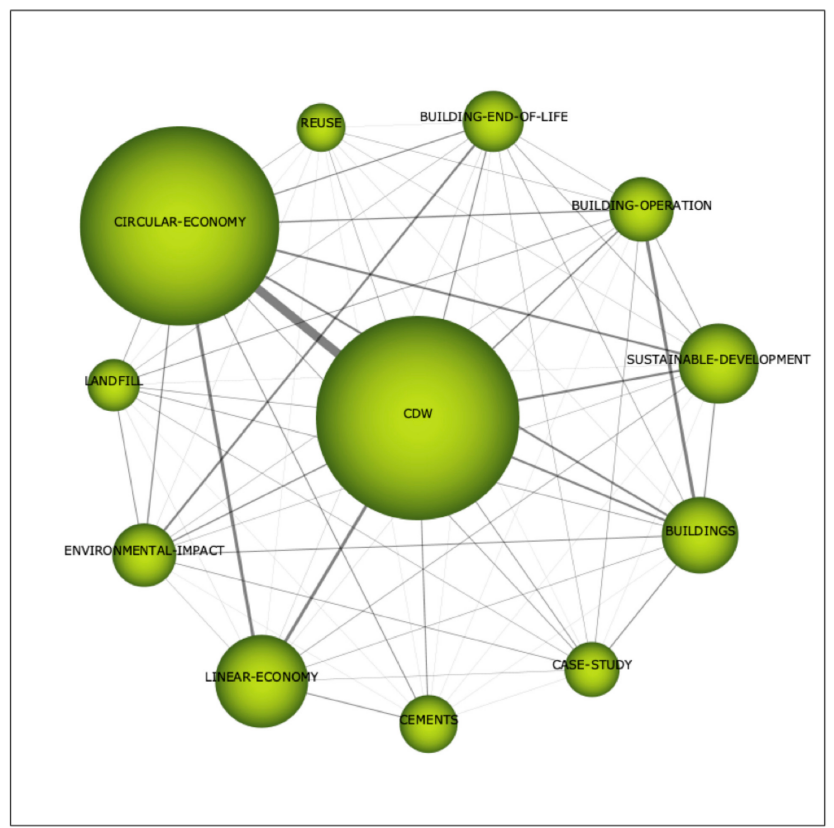

Figure 5. Thematic networks by (a) period 1, (b) period 2 and (c) period 3.

\subsubsection{Selection of the Literature}

Once the selected keywords and search strings for searching the Scopus and ISIWoS databases had been identified, the records obtained were collected and archived. The PRISMA flowchart guide was then applied (Figure 2), showing the number of relevant documents identified. 
(a) Overlay graph

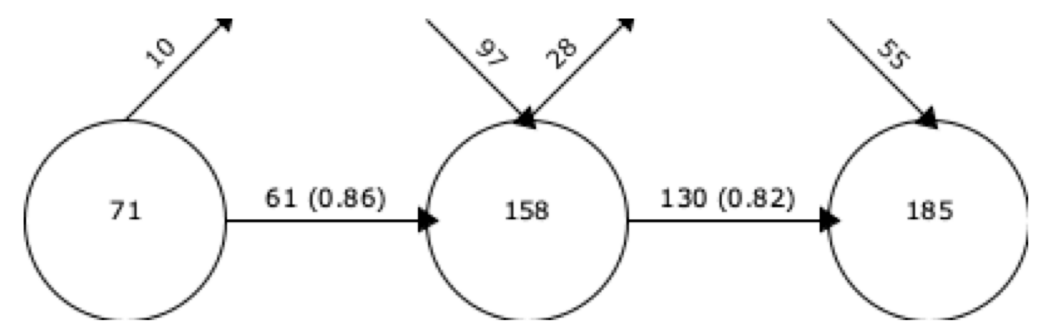

(b) Thematic evolution map

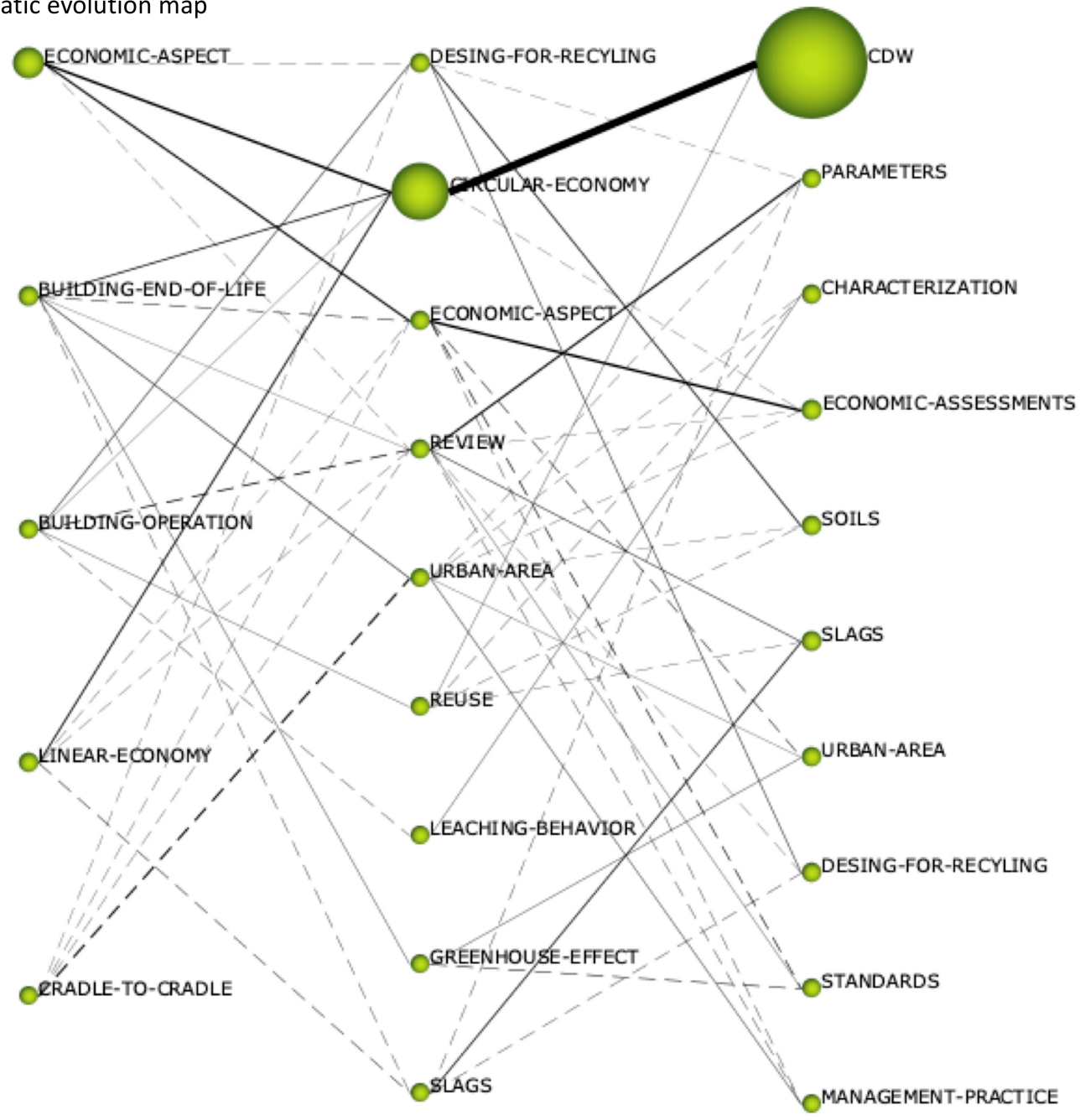

Figure 6. (a) Overlay graph and (b) thematic evolution map.

A total of 1995 bibliographic records were retrieved from the two selected databases. After removing 317 duplicates, 154 of the remaining 1678 records were excluded, applying the exclusion criteria (only documents of article type, complete document, related to the field of research and documents in English). Next, the remaining 1524 records were screened for title, abstract and keywords, and 84 additional records were excluded as they did not cover the topics included in this review. Finally, 1440 relevant documents were selected for the study. 
Table 1. Keywords related to the research topics.

\begin{tabular}{|c|c|c|c|}
\hline Theme & Keywords Related & Definition of the Keyword & Ref. \\
\hline \multirow{12}{*}{ Circular economy } & Circular Economy & $\begin{array}{l}\text { The circular economy seeks to maintain building components and resources at } \\
\text { their highest intrinsic value for as long as possible. Building components are } \\
\text { kept in a continuous cycle of use, reuse, repair and then recycled, thus reducing } \\
\text { waste and preventing negative externalities such as } \mathrm{CO} 2 \text { emissions. }\end{array}$ & [20] \\
\hline & Cradle to cradle & $\begin{array}{l}\text { The design and production of products of all types in such a way that at the end } \\
\text { of their life, they can be truly recycled (upcycled), imitating nature's cycle with } \\
\text { everything either recycled or returned to the earth. }\end{array}$ & [65] \\
\hline & 3R principle & CDW management based on three key concepts: reuse, recycling and reduction. & [66] \\
\hline & Industrial ecology & $\begin{array}{l}\text { Industrial Ecology (IE) is a study aimed at understanding the circulation of } \\
\text { materials and energy flows; therefore, IE must first understand how the } \\
\text { industrial ecosystem works, how it is managed and its relations with the } \\
\text { biosphere to determine how the industrial ecosystem can be restructured to } \\
\text { resemble how natural ecosystems function. }\end{array}$ & [67] \\
\hline & Green economy & $\begin{array}{l}\text { Low carbon, resource efficient and socially inclusive [where] growth in income } \\
\text { and employment should be driven by public and private investments that } \\
\text { reduce carbon emissions and pollution, enhance energy and resource efficiency } \\
\text { and prevent the loss of biodiversity and ecosystem services. }\end{array}$ & [68] \\
\hline & Industrial symbiosis (IS) & $\begin{array}{l}\text { Industrial symbiosis falls under the principle of the CE and is recognised as a } \\
\text { useful strategy to support the transition from a linear to a circular economy. IS } \\
\text { involves flows and the cycling of materials and energy, as well as synergic } \\
\text { interactions between firms through which wastes are converted into inputs. }\end{array}$ & {$[69,70]$} \\
\hline & Closed loop & \multirow{3}{*}{$\begin{array}{l}\text { An economic model based inter alia on sharing, leasing, reuse, repair, } \\
\text { refurbishment and recycling, in an (almost) closed loop, which aims to retain the } \\
\text { highest utility and value of products, components and materials at all times. }\end{array}$} & \multirow{3}{*}{ [71] } \\
\hline & Closing the loop & & \\
\hline & Downcycling & & \\
\hline & Recycling & $\begin{array}{l}\text { Capturing materials that would otherwise go to waste to save natural resources } \\
\text { and the energy that it used to extract and transform natural resources into } \\
\text { finished products. }\end{array}$ & [72] \\
\hline & Reuse & $\begin{array}{l}\text { Reuse is the action or practice of using an item, whether for its original purpose } \\
\text { or to fulfil a different function (creative reuse or repurposing). Reuse-by } \\
\text { taking, but not reprocessing, previously used items-helps save time, money, } \\
\text { energy and resources. }\end{array}$ & \\
\hline & Reduce & & \\
\hline $\begin{array}{l}\text { Construction and } \\
\text { demolition waste } \\
\quad(\text { CDW })\end{array}$ & $\begin{array}{l}\text { Construction and demolition } \\
\text { waste }\end{array}$ & $\begin{array}{c}\text { CDW, come from the construction, renovation, expansion and demolition of all } \\
\text { types of buildings, structures and piping networks and residential decoration } \\
\text { activity. They consist of different materials such as concrete, bricks and blocks, } \\
\text { ceramics, mortar, metal, wood and plastic available in varying fractions } \\
\text { depending on the geographical location of the construction or demolition } \\
\text { project. These materials can be classified into three categories: inert waste, } \\
\text { non-inert waste and contaminated waste. }\end{array}$ & {$[73-76]$} \\
\hline
\end{tabular}

\subsubsection{Identification of Periods}

The identification of periods was determined based on the main milestones and turning points in the evolution of EC and CDW. The time horizon used was from 1993 to 2020, given that the inclusion in the scientific literature of fundamental issues from which CE stems took place in the 1990s. It was then subdivided into the following three periods, considering the number of papers selected, as well as relevant milestones to analyse trends in publication patterns:

First period (1993-2008): 141. The EC concept was implemented through government policies at local, regional and national levels.

Second period (2009-2015): 392. A relevant milestone that started this period is Directive 2008/98/EC, which is considered an initial document on implementing best practice in waste management. Thus, the European Union started to develop strategies that promote economic growth, prevent the loss of valuable materials and reduce environmental impact and greenhouse gases emissions. The Chinese government incorporated EC 11019 as a central pillar of its national economic and social development plans. Subsequently, 
in 2009, it established the Circular Economy Promotion Law of the People's Republic of China [77].

Third period (2016-2020): 974. The European Union delivered the Communications "Towards a circular economy: a zero-waste agenda for Europe" (COM 398, 2014) in 2014, and in 2015, "Closing the loop. An EU Action Plan for the Circular Economy" (COM 614, 2015). Both communications are part of the "Circular Economy Package", which consists of multiple action plans and legislative proposals focusing on each step of the value chain (production, consumption, waste management and secondary raw materials) in five priority sectors: plastics, food waste, critical raw materials, construction and demolition and biomass and bio-based products.

Finally, in 2020, "The new Circular Economy Action Plan" [78] was established as a fundamental pillar supporting the European Green Deal to achieve the expected European climate neutrality by 2050 .

Figure 3 shows the distribution of 1440 publications per year. It is observed that circular economy applied to CDW is generally a new global sustainable development trend that has started to gain momentum in the construction industry. The assessment showed a gradual building of awareness in the field, which is evident from the number of publications since 2016. Most of the papers in this systematic review were published between 2016 and 2020, which is a clear indication of growing research interest, and the projection of this analysis indicates that this number will continue to increase.

\subsection{Bibliometric Analysis: Science Mapping and Performance Analysis \\ 3.2.1. Science Mapping}

In this section, the following graphs are analysed and discussed: strategic diagrams, one for each period; thematic networks of the critical themes; overlay graph and the thematic evolution map. The evolution of the time horizon of the documents, the number of citations of the documents and the most cited authors and publications are analysed quantitatively and qualitatively.

\section{Strategic Diagrams}

Three strategic diagrams (shown in Figure 4) were generated to analyse changes over time in the research field for the four periods considered (1993-2008, 2009-2015 and 2016-2020), where the spheres' magnitude is related to the number of publications associated with each research topic. Table 2 shows the performance measures that have been acquired, in relation with each topic and time, based on the number of documents, $\mathrm{h}$-index and centrality and density values. In the following, the outcomes of the study are described, according to each period.

First period (1993-2008). The strategic diagram in Figure 4a shows five research themes can be observed in the 141 papers selected in this period. Of these, two were considered driving themes (economic aspect and building operation), one a highly developed and isolated theme (cradle to cradle), one emerging or declining (linear economy) and finally, one considered essential (building end of life).

The performance analysis for each theme, as shown in Table 2, complements the information provided by the diagram, which highlights how the two themes with the highest performance measures are "economic aspect" and "Building-end of life". These themes have more than 5000 citations between them, obtaining a higher h-index than the rest of the themes.

Second period (2009-2015). Based on the diagram shown in Figure 5b, eight themes can be observed in the 392 papers selected in this period. Four of these themes were considered as driving themes (Design for Recycling, Circular Economy, Review and Urban Area), one highly developed and isolated theme (Leaching Behaviour), two emerging or declining themes (Reuse and Greenhouse Effect) and finally, one basic theme (Economic Aspect). 
According to the performance measures (Table 2), the following three themes can be highlighted: "Circular Economy", "Economic Aspect" and "Review". These research topics had a high impact rate and achieved a higher h-index than the other topics.

Third period (2016-2020). According to the strategic outline presented in Figure 5c, nine research themes can be observed in the 974 selected papers in this period. Four of these are considered driving themes (CDW, Parameters, Characterisation and Urban Area), two highly developed and isolated themes (Standards and Management Practice), three emerging or declining (Soils and Design for Recycling) and finally, one theme is considered essential, Economic Assessments.

According to the performance measures (Table 2), the following two themes can be highlighted: CDW and Economic Assessments. These research themes scored high impact and achieved a higher h-index than the other themes.

Table 2. Performance measures of the themes.

\begin{tabular}{|c|c|c|c|c|c|}
\hline Name & No. of Documents & No. of Citations & h-Index & Centrality & Density \\
\hline \multicolumn{6}{|c|}{ Period 1 (1993-2008) } \\
\hline Economic-Aspect & 122 & 4905 & 39 & 74.23 & 50.8 \\
\hline Building-End-of-Life & 16 & 735 & 10 & 37.02 & 19.46 \\
\hline Building-Operation & 8 & 630 & 5 & 33.54 & 46.59 \\
\hline Linear-Economy & 10 & 497 & 6 & 27.17 & 3.78 \\
\hline Cradle-to-Cradle & 1 & 31 & 1 & 3.77 & 306.25 \\
\hline \multicolumn{6}{|c|}{ Period 2 (2009-2015) } \\
\hline Design-for-Recycling & 11 & 312 & 6 & 132.93 & 31.71 \\
\hline Circular-Economy & 371 & 11,910 & 60 & 90.39 & 48.78 \\
\hline Economic-Aspect & 9 & 527 & 7 & 70.18 & 16.78 \\
\hline Review & 8 & 610 & 8 & 37.17 & 19.99 \\
\hline Urban-Area & 3 & 160 & 3 & 93.23 & 44.52 \\
\hline Reuse & 4 & 158 & 4 & 27.69 & 9.75 \\
\hline Leaching-Behaviour & 3 & 101 & 3 & 10.04 & 18.75 \\
\hline Greenhouse-Effect & 3 & 160 & 3 & 19.57 & 8.33 \\
\hline \multicolumn{6}{|c|}{ Period 3 (2016-2020) } \\
\hline CDW & 883 & 8928 & 44 & 59.53 & 50.52 \\
\hline Parameters & 7 & 67 & 5 & 57.08 & 22.39 \\
\hline Characterisation & 10 & 156 & 7 & 40.3 & 25.58 \\
\hline Economic-Assessments & 19 & 267 & 8 & 34.67 & 6.65 \\
\hline Soils & 13 & 29 & 3 & 26.55 & 10.38 \\
\hline Urban-Area & 11 & 147 & 4 & 32.53 & 21.86 \\
\hline Design-for-Recycling & 10 & 76 & 4 & 15.9 & 12.92 \\
\hline Standards & 5 & 14 & 2 & 7.14 & 22.55 \\
\hline Management-Practice & 2 & 51 & 2 & 9.69 & 32.54 \\
\hline
\end{tabular}

Thematic Networks

In this section, to further explore relevant themes and future trends, three thematic networks, one per period, were selected based on their saliency, which captures developed, basic and emerging research over time. The interconnections between the themes (circles) are represented in Figure 5. The circle size indicates the number of documents, and the 
thickness of the line corresponds to the strength of the correlation between the two nodes. An analysis of the results obtained for each period is shown below.

The theme "Building End of Life" is defined as building end of life programs and loop systems. Interventions to either restore, reuse or recycle a building's components are worth mentioning as one of the most characteristic themes of the first period if analysed from the point of view of its thematic network. Thus, in Figure 5a, we can see that issues related to the final stage of the life cycle of buildings are considered essential in the early years of the field where research was heading. This theme is closely linked to other essential themes such as "Decision Support System", "Closed Loop" and "Environmental Impact", of which have been numerous studies. The opportunity presented by CDW is already emerging. It reflects the emphasis on recovering and reusing building construction products at the end of their useful life, rather than destructive demolition and recycling. While there is now a trade in the recovery and reuse of non-structural and heritage products, in the early days of the research, the most significant volume, mass and value of buildings comprised structural elements (concrete, brick and masonry and steel), which still present many challenges today.

The "Circular Economy" theme is considered one of the most relevant themes of the second period. As can be seen in Figure 5b, this theme is closely linked to other essential themes such as "CDW", "Building" and "Green Economy". Furthermore, we can see that the issues of closing the loop and the environmental impact of building sustainability and decision support systems are consolidated after implementing the first CDW regulations to give way to the definition of the circular economy concept in CDW. It becomes clear that the transition from the linear to the circular economy (Figure $4 a, b$ ) was not realised until the principles of the circular economy were applied in the life cycle stages of buildings, which constitutes a proactive design approach to manage buildings from cradle to cradle [79].

Finally, in the last one, the theme of "CDW" is considered vital today. As can be seen in Figure 5c, this theme is closely linked to other essential themes such as "Sustainable Development", "Building Operation" and "Circular Economy". In this sense, as an innovative economic and productive model, the $\mathrm{CE}$ in building principal implies a change in mentality that considers waste as potentially valuable resources rather than as a problem of management and disposal in landfills, as in the past linear economy [80].

\section{Overlay Graph and Thematic Evolution Map}

The strategic outlines and thematic networks reflect scientists' involvement and interest in some topics corresponding to a growing awareness of sustainability issues. During the first few years, a robust concern for the economic impact of waste has been revealed. In the 1990s and early years of the 21st century, the concept of linear economy starts to disappear based on cradle-to-cradle principles, giving way to relevant topics such as building operation. Since 2009, there has been a great interest in topics such as design for recycling and urban area, the latter reflecting new lines of research in the field of sustainable and resilient cities. In addition, following the introduction of regulations, the concept of circular economy was linked to the concept of DRC. More recently, interest has focused, in parallel to sustainable development, on issues related to the assessment and parameterisation of $\mathrm{CDM}$ in order to manage it and introduce it into regulations, based on the consolidation of sustainable building assessment methods (SBAMs). In SBAMs, the assessment of CDW management has a very significant burden.

Finally, to analyse the evolution of topics over time, Figure $6 a, b$ represents the keywords based on the period and their evolution, the incoming and outgoing keywords and the number and percentage of keywords maintained from one period to the next. As shown in Figure 6a, the number of keywords increases over the periods, parallel with the increase in the number of documents over the years. The number of keywords increases from 71 to 185 between the first and the last period, a growth rate of $123 \%$. Specifically, of 71 keywords that appeared in the first period, $86 \%$ (61) remain in the second period and 97 new words are added, giving a total of 158 words. Finally, in the third period, $130(82 \%)$ keywords 
remain from the second period, while new 55 appear, for a total amount of 185, resulting in a high number of new and transitional keywords and a growing level in shared keywords in subsequent times. Consequently, the rising variety of subjects in CE research applied to DCRs and the fact that keywords reappear more strongly in the following periods could indicate that this relatively new research field is gradually consolidating.

Finally, Figure $6 \mathrm{~b}$ shows the thematic evolution of the research field by analysing the topics sources and correlations. The lines sizes are proportional to the robustness of the relationship as estimated according to the inclusion index. In terms of publications number, "Economic Aspects" appeared as the topic with the highest number of documents between 1993 and 2008 and evolved towards the themes of "Design for Recycling", "Circular Economy" and "Review" in the second period (2009-2015). Between the second and third period, the theme of "Economic Aspects" was decreasing and evolving towards themes such as "Evaluation and Standards", "Urban Areas" and "Management Practices". Similarly, in the early years, the "Cradle-to-Cradle" theme laid the foundation for themes such as "Design for Recycling" and "Circular Economy".

For the second period, the theme "Circular Economy" appeared with the highest number of documents and evolved into the themes of "RCD" and "Economic Assessment" in 2016-2020. Furthermore, in this period, the theme "Reuse" replaced the importance of the theme "Design for Recycling", as recycling is no longer considered as necessary as reuse.

\subsubsection{Performance Analysis}

The 1440 documents analysed received 24,591 citations. Table 3 shows the ten publications with the highest number of citations, 2820 , or $23 \%$ of the total. The most cited papers focus on different aspects of the thematic field analysed, revealing its diversity. These papers deal with the substitution of various recycled materials for aggregates to reduce the need to extract virgin aggregates; the need for comprehensive and integrated CDW management mechanisms, technologies, sorting systems and policies; the scarcity of landfills and the long-term adverse environmental, economic and social impacts of CDW; the sustainable management of CDW, among others. These are based on the increasing pressure on the construction industry to reduce costs and improve the quality of our environment, looking for alternative solutions to manage and control this critical type of waste in an economically efficient and environmentally safe way.

On the other hand, concerning the journals presenting the largest number of publications, Table 4 shows the ten prominent ones out of the 121 collected in this review. These ten publications account for $24.1 \%$ of the analysed documents, listed in descending order according to the number of citations. Most of them are research journals focusing on construction and building materials and new construction and repair practices, on environmental and sustainability issues in corporations, governments, regions and societies, among others. Table 4 also includes the most frequently cited paper in each journal. As shown, the number of publications and citations is not closely related because only four of the top journals are also among the top five in several citations in terms of several articles. In other words, the most prolific sources have not necessarily been those with the highest research impact. A systematic literature review allowed the identification of 4567 authors who have published articles dealing with the topic of the study. Table 5 shows those authors with more than ten published studies, sorted by total number of documents published; it also incorporates the number of citations received, as well as the h-index (Hirsch index), a measure of the authors' professional quality according to the number of times that their scientific articles have been cited. According to the analysis, J De Brito, J. [81] has published the most articles on the topic of CE and CDW and has the highest index for the number of citations, thus, the highest h-index. 
Table 3. Most-cited documents.

\begin{tabular}{|c|c|c|c|c|}
\hline Title & Authors & Year & No. Citations & Ref. \\
\hline The greening of the concrete industry & Meyer, C. & 2009 & 604 & [82] \\
\hline $\begin{array}{l}\text { Use of aggregates from recycled construction and } \\
\text { demolition waste in concrete }\end{array}$ & Rao, A., Jha, K.N., Misra, S. & 2007 & 390 & [83] \\
\hline $\begin{array}{l}\text { Properties and composition of recycled aggregates } \\
\text { from construction and demolition waste suitable for } \\
\text { concrete production }\end{array}$ & Silva, R.V., Dhir, R.K., De Brito, J. & 2014 & 382 & [81] \\
\hline $\begin{array}{l}\text { Recycled aggregate from C\&D waste \& its use in } \\
\text { concrete-A breakthrough towards sustainability in } \\
\text { construction sector: A review }\end{array}$ & $\begin{array}{l}\text { Bhattacharyya, S.K., Behera, M., } \\
\text { Minocha, A.K., Deoliya, R., Maiti, S. }\end{array}$ & 2014 & 346 & [33] \\
\hline $\begin{array}{l}\text { Trend of the research on construction and demolition } \\
\text { waste management }\end{array}$ & Yuan, H., Shen, L. & 2011 & 235 & [84] \\
\hline $\begin{array}{l}\text { Energy indices and ratios for sustainable material } \\
\text { cycles and recycle options }\end{array}$ & Brown, M.T., Buranakarn, V. & 2003 & 215 & [85] \\
\hline $\begin{array}{l}\text { Estimation of construction waste generation and } \\
\text { management in Thailand }\end{array}$ & Kofoworola, O.F., Gheewala, S.H. & 2009 & 171 & [86] \\
\hline $\begin{array}{c}\text { An overview of construction and demolition waste } \\
\text { management in Canada: A lifecycle analysis } \\
\text { ap-proach to sustainability }\end{array}$ & $\begin{array}{l}\text { Yeheyis, M., Hewage, K., Alam, M.S., } \\
\text { Eskicioglu, C., Sadiq, R. }\end{array}$ & 2013 & 171 & [87] \\
\hline $\begin{array}{l}\text { Strategies for successful construction and demolition } \\
\text { waste recycling operations }\end{array}$ & Peng, C.-L., Scorpio, D.E., Kibert, C.J. & 1997 & 154 & [88] \\
\hline $\begin{array}{l}\text { Environmental management of construction and } \\
\text { demolition waste in Kuwait }\end{array}$ & $\begin{array}{l}\text { Kartam, N., Al-Mutairi, N., } \\
\text { Al-Ghusain, I., Al-Humoud, J. }\end{array}$ & 2004 & 152 & [89] \\
\hline
\end{tabular}

Table 4. Main journals contributing to the research field.

\begin{tabular}{|c|c|c|c|c|c|}
\hline Name & $\begin{array}{l}\text { No. of Documents } \\
\text { Citation Indexes of } \\
\text { the Journal }\end{array}$ & $\begin{array}{l}\text { No. of Citation } \\
\text { Indexes of the } \\
\text { Journal }\end{array}$ & Most Cited Document & $\begin{array}{l}\text { Number of Citations } \\
\text { in the Document }\end{array}$ & Ref. \\
\hline $\begin{array}{l}\text { Construction and } \\
\text { Building Materials }\end{array}$ & 141 & 5446 & $\begin{array}{l}\text { Properties and composition of } \\
\text { recycled aggregates from construction } \\
\text { and demolition waste suitable for } \\
\text { concrete production }\end{array}$ & 382 & [81] \\
\hline $\begin{array}{l}\text { Journal of Cleaner } \\
\text { Production }\end{array}$ & 121 & 3297 & $\begin{array}{l}\text { Mechanical performance of concrete } \\
\text { made with aggregates from } \\
\text { construction and demolition waste } \\
\text { recycling plants }\end{array}$ & 152 & [90] \\
\hline Waste Management & 87 & 2668 & $\begin{array}{l}\text { Trend of the research on construction } \\
\text { and demolition waste management }\end{array}$ & 235 & [84] \\
\hline $\begin{array}{l}\text { Resources, } \\
\text { Conservation and } \\
\text { Recycling }\end{array}$ & 69 & 3394 & $\begin{array}{l}\text { Evaluation of the economic feasibility } \\
\text { for the recycling of construction and } \\
\text { demolition waste in China-The case } \\
\text { of Chongqing }\end{array}$ & 145 & [91] \\
\hline $\begin{array}{l}\text { Waste Management } \\
\text { and Research }\end{array}$ & 50 & 647 & $\begin{array}{l}\text { Sustainable construction: } \\
\text { Construction and demolition waste } \\
\text { reconsidered }\end{array}$ & 81 & [92] \\
\hline $\begin{array}{l}\text { Sustainability } \\
\text { (Switzerland) }\end{array}$ & 33 & 116 & $\begin{array}{l}\text { A dynamic model for construction } \\
\text { and demolition (C\&D) waste } \\
\text { management in Spain: Driving } \\
\text { policies based on economic incentives } \\
\text { and tax penalties }\end{array}$ & 35 & [93] \\
\hline Materials & 27 & 165 & $\begin{array}{l}\text { Life Cycle Assessment of Completely } \\
\text { Recyclable Concrete }\end{array}$ & & [94] \\
\hline $\begin{array}{l}\text { Journal of Materials } \\
\text { in Civil Engineering }\end{array}$ & 20 & 402 & $\begin{array}{l}\text { Recycled red-clay ceramic } \\
\text { construction and demolition waste for } \\
\text { mortars production }\end{array}$ & & [95] \\
\hline
\end{tabular}


Table 4. Cont.

\begin{tabular}{ccccc}
\hline Name & $\begin{array}{c}\text { No. of Documents } \\
\text { Citation Indexes of } \\
\text { the Journal }\end{array}$ & $\begin{array}{c}\text { No. of Citation } \\
\text { Indexes of the } \\
\text { Journal }\end{array}$ & Most Cited Document & $\begin{array}{c}\text { Number of Citations } \\
\text { in the Document }\end{array}$ \\
\hline $\begin{array}{c}\text { Environmental } \\
\text { Science and Pollution } \\
\text { Research }\end{array}$ & 19 & 9 & $\begin{array}{c}\text { An environmental assessment model } \\
\text { of construction and demolition waste } \\
\text { based on system dynamics: a case } \\
\text { study in Guangzhou }\end{array}$ & 90 \\
\hline $\begin{array}{c}\text { Cement and Concrete } \\
\text { Composites }\end{array}$ & 16 & 1475 & The greening of the concrete industry & 604 \\
\hline
\end{tabular}

Table 5. Authors with more than twenty published studies in the research field.

\begin{tabular}{|c|c|c|c|c|c|c|}
\hline Name & $\begin{array}{c}\text { No. of } \\
\text { Documents }\end{array}$ & $\begin{array}{l}\text { Total Citations } \\
\text { in This Work }\end{array}$ & h-Index & Most Cited Document & $\begin{array}{l}\text { Number of } \\
\text { Citations in } \\
\text { the Document }\end{array}$ & Ref. \\
\hline De Brito, J. & 36 & 2984 & 64 & $\begin{array}{l}\text { Properties and composition of } \\
\text { recycled aggregates from } \\
\text { construction and demolition waste } \\
\text { suitable for concrete production }\end{array}$ & 382 & [81] \\
\hline Tam, V.W.Y. & 27 & 760 & 54 & $\begin{array}{l}\text { A review of recycled aggregate in } \\
\text { concrete applications (2000-2017) }\end{array}$ & 149 & [97] \\
\hline Ayuso, J. & 24 & 711 & 18 & $\begin{array}{l}\text { Maximum feasible use of recycled } \\
\text { sand from construction and } \\
\text { demolition waste for eco-mortar } \\
\text { production-Part-I: Ceramic } \\
\text { masonry waste }\end{array}$ & 54 & [98] \\
\hline Wang, J. & 20 & 418 & 25 & $\begin{array}{c}\text { Characterizing the generation and } \\
\text { flows of construction and } \\
\text { demolition waste in China }\end{array}$ & 86 & [99] \\
\hline
\end{tabular}

\section{Discussions}

From the above results, it can be inferred that the circular economy paradigm has the potential to overcome the problems resulting from the adoption of the linear economic model by the construction sector. Although environmental sustainability in construction is a broad research topic, the results show that academic studies and reviews of the literature on circular economy applied to CDWs are limited, although they have increased rapidly in recent years; however, still, all stakeholders in the construction sector require serious measures to improve the adoption of the circular economy. Furthermore, the lack of environmental regulations and laws is found to be driving significant barriers to the circular economy. Likewise, critical is the lack of public awareness and support from public institutions.

The above results show that CDWs are considered necessary resources for social development and that they provide economic and environmental benefits. CDW management practices also varied in developed and developing countries and are influenced by population, urbanisation, GDP, CDW policies and standards. However, CDW management is not fully employed due to economic and legal barriers due to the profit-driven and change-resistant nature of the construction industry. Barriers against the use of CDW included insufficient design standards, low cost of waste disposal over recycling, inadequate urban planning, immature recycled waste market, lack of CDW processing, lack of performance measurements, human factors and integration with technological advances, ineffective management of CDW, transportation issues, CDW ownership and uncertainty after implementing CDW, among others.

However, official policies and regulations, smart deconstruction, government incentives, a collaboration of key stakeholders, improving the quality of CDW material, 
certification of recycled products and advanced recycling technologies are key to improving the sector. On the other hand, due to increased urbanisation in developing countries, construction activity is increasing. Therefore, there is great potential to implement CE in the construction sector.

\section{Conclusions}

In this work, a systematic review of the literature and bibliometric analysis of 1440 bibliographic records on CE applied to CDW was carried out using the SciMAT software. The main themes and their development in this field from 1993 to 2020 were identified.

The results show a dynamic research field in continuous development. In particular, one of the aspects of the study that reaffirms the thematic richness of the circular economy and construction, and demolition waste is the large number of keywords used in the studies consulted. Specifically, the evolution of the study topics over time shows that in each period, the subject has focused on different aspects, from its first point of view on concepts "Cradle-To-Cradle" and "Economic Aspects" to the inclusion of thematic and thematic indicators of the research field in different periods, until the gradual inclusion of social and economic aspects.

In the first period, the authors focused on the problem of the management of construction and demolition waste derived from the activity of the sector. In the second period, the characterisation of the different types of recycled aggregates and their possible applications in the substitution of natural ones was studied in depth. The third period shows the influence of government policies on the recovery of construction and demolition waste to achieve circularity and environmental sustainability in the sector.

This study highlights in the field of research the relevant turning points, the obligation to manage waste, standardise it and enable its reuse. It highlights the trends aimed at characterising waste, parameterising them to incorporate them into technical standards within the framework of the strategic lines of smart cities.

This study aims to contribute to the body of knowledge by highlighting trends and patterns in the research field, establishing its research topics, mapping researchers' networks and recommending areas for future study.

Author Contributions: Conceptualisation, C.D.-L., A.B., M.M.-M. and M.Z.; methodology, C.D.-L., A.B., M.M.-M. and M.Z.; software, C.D.-L.; validation, C.D.-L., A.B., M.M.-M. and M.Z.; formal analysis, C.D.-L., A.B., M.M.-M. and M.Z.; investigation, C.D.-L., A.B., M.M.-M. and M.Z.; resources, C.D.-L., A.B., M.M.-M. and M.Z.; data curation, C.D.-L.; writing-original draft preparation, C.D.-L., A.B., M.M.-M. and M.Z.; writing-review and editing, C.D.-L., A.B., M.M.-M. and M.Z.; visualisation, C.D.-L., A.B., M.M.-M. and M.Z.; supervision, C.D.-L., A.B., M.M.-M. and M.Z. All authors have read and agreed to the published version of the manuscript.

Funding: This research received no external funding.

Institutional Review Board Statement: Not applicable.

Informed Consent Statement: Not applicable.

Data Availability Statement: Not applicable.

Acknowledgments: This research was supported by research group TEP-968 Tecnologías para la Economía Circular (Technologies for Circular Economy) of the University of Granada.

Conflicts of Interest: The authors declare no conflict of interest.

\section{References}

1. Cole, R.J. Shared Markets: Coexisting Building Environmental Assessment Methods. Build. Res. Inf. 2006, 34, 357-371. [CrossRef]

2. Alsaeed, Y.; Ahmed, A.; Gaterell, M. Investigating the Inter-Relationships between Resilience and Sustainability of Built Environment. In Proceedings of the 2nd International Conference on Urban Sustainability and Resilience, University College London, London, UK, 3-5 November 2014. 
3. Cai, G.; Waldmann, D. A Material and Component Bank to Facilitate Material Recycling and Component Reuse for a Sustainable Construction: Concept and Preliminary Study. Clean Technol. Environ. Policy 2019, 21, 2015-2032. [CrossRef]

4. Boer, D.; Segarra, M.; Fernández, A.I.; Vallès, M.; Mateu, C.; Cabeza, L.F. Approach for the Analysis of TES Technologies Aiming towards a Circular Economy: Case Study of Building-like Cubicles. Renew. Energy 2020, 150, 589-597. [CrossRef]

5. Iacovidou, E.; Velis, C.A.; Purnell, P.; Zwirner, O.; Brown, A.; Hahladakis, J.; Millward-Hopkins, J.; Williams, P.T. Metrics for Optimising the Multi-Dimensional Value of Resources Recovered from Waste in a Circular Economy: A Critical Review. J. Clean. Prod. 2017, 166, 910-938. [CrossRef]

6. Clark, C.; Jambeck, J.; Townsend, T. A Review of Construction and Demolition Debris Regulations in the United States. Crit. Rev. Environ. Sci. Technol. 2006, 36, 141-186. [CrossRef]

7. Baiani, S.; Altamura, P. Waste Materials Superuse and Upcycling in Architecture: Design and Experimentation. TECHNE 2018, 16, 142-151. [CrossRef]

8. European Commission Circular Economy Action Plan. Eur. Comm. 2020, 28. [CrossRef]

9. Brambilla, G.; Lavagna, M.; Vasdravellis, G.; Castiglioni, C.A. Environmental Benefits Arising from Demountable Steel-Concrete Composite Floor Systems in Buildings. Resour. Conserv. Recycl. 2019, 141, 133-142. [CrossRef]

10. Akanbi, L.A.; Oyedele, L.O.; Akinade, O.O.; Ajayi, A.O.; Delgado, M.D.; Bilal, M.; Bello, S.A. Salvaging Building Materials in a Circular Economy: A BIM-Based Whole-Life Performance Estimator. Resour. Conserv. Recycl. 2018, 129, 175-186. [CrossRef]

11. Heiselberg, P.K.; Pomianowski, M.Z. Novel Methodology toward Nearly Zero Energy Building (NZEB) Renovation: Cost-Effective Balance Approach as a Pre-Step to Cost-Optimal Life Cycle Cost Assessment. Appl. Sci. 2021, 11, 4141.

12. Norouzi, M.; Chàfer, M.; Cabeza, L.F.; Jiménez, L.; Boer, D. Circular Economy in the Building and Construction Sector: A Scientific Evolution Analysis. J. Build. Eng. 2021, 102704. [CrossRef]

13. Mhatre, P.; Gedam, V.; Unnikrishnan, S.; Verma, S. Circular Economy in Built Environment—Literature Review and Theory Development. J. Build. Eng. 2021, 35, 101995. [CrossRef]

14. Akhimien, N.G.; Latif, E.; Hou, S.S. Application of Circular Economy Principles in Buildings: A Systematic Review. J. Build. Eng. 2021, 38, 102041. [CrossRef]

15. Eberhardt, L.C.M.; Rønholt, J.; Birkved, M.; Birgisdottir, H. Circular Economy Potential within the Building Stock-Mapping the Embodied Greenhouse Gas Emissions of Four Danish Examples. J. Build. Eng. 2021, 33, 101845. [CrossRef]

16. Committee and the Committee of the Regions. Towards a Circular Economy: A Zero Waste Programme for Europe Towards a Circular Economy: A Zero Waste Programme for Europe; Committee and the Committee of the Regions: Brussels, Belgium, 2019.

17. Díaz-López, C.; Jódar, J.; Verichev, K.; Rodríguez, M.L.; Carpio, M.; Zamorano, M. Dynamics of Changes in Climate Zones and Building Energy Demand. A Case Study in Spain. Appl. Sci. 2021, 11, 4261. [CrossRef]

18. Díaz-López, C.; Navarro-Galera, A.; Zamorano, M.; Buendía-Carrillo, D. Identifying Public Policies to Promote Sustainable Building: A Proposal for Governmental Drivers Based on Stakeholder Perceptions. Sustainability 2021, 13, 7701. [CrossRef]

19. Díaz-López, C.; Carpio, M.; Martín-Morales, M.; Zamorano, M. Defining strategies to adopt Level(s) for bringing buildings into the circular economy. A case study of Spain. J. Clean. Prod. 2021, 287, 125048. [CrossRef]

20. Behrens, A.; Giljum, S.; Kovanda, J.; Niza, S. The Material Basis of the Global Economy. Worldwide Patterns of Natural Resource Extraction and Their Implications for Sustainable Resource Use Policies. Ecol. Econ. 2007, 64, 444-453. [CrossRef]

21. Noyons, E.C.M.; Moed, H.F.; Luwel, M. Combining Mapping and Citation Analysis for Evaluative Bibliometric Purposes: A Bibliometric Study. J. Am. Soc. Inf. Sci. 1999, 50, 115-131. [CrossRef]

22. van Nunen, K.; Li, J.; Reniers, G.; Ponnet, K. Bibliometric Analysis of Safety Culture Research. Saf. Sci. 2018, 108, 248-258. [CrossRef]

23. Osareh, F. Bibliometrics, Citation Analysis and Co-Citation Analysis: A Review of Literature I. Libri 1996, 46, 149-158. [CrossRef]

24. Roig-Tierno, N.; Gonzalez-Cruz, T.F.; Llopis-Martinez, J. An Overview of Qualitative Comparative Analysis: A Bibliometric Analysis. J. Innov. Knowl. 2017, 2, 15-23. [CrossRef]

25. Small, H. Visualizing Science by Citation Mapping. J. Am. Soc. Inf. Sci. 1999, 50, 799-813. [CrossRef]

26. Albort-Morant, G.; Ribeiro-Soriano, D. A Bibliometric Analysis of International Impact of Business Incubators. J. Bus. Res. 2016, 69, 1775-1779. [CrossRef]

27. Liberati, A.; Altman, D.G.; Tetzlaff, J.; Mulrow, C.; Gøtzsche, P.C.; Ioannidis, J.P.A.; Clarke, M.; Devereaux, P.J.; Kleijnen, J.; Moher, D. The PRISMA Statement for Reporting Systematic Reviews and Meta-Analyses of Studies That Evaluate Health Care Interventions: Explanation and Elaboration. PLoS Med. 2009, 6, e1000100. [CrossRef] [PubMed]

28. Antman, E.M.; Lau, J.; Kupelnick, B.; Mosteller, F.; Chalmers, T.C. A Comparison of Results of Meta-Analyses of Randomized Control Trials and Recommendations of Clinical Experts. JAMA 1992, 268, 240-248. [CrossRef]

29. Martínez-Aires, M.D.; López-Alonso, M.; Martínez-Rojas, M. Building Information Modeling and Safety Management: A Systematic Review. Saf. Sci. 2018, 101, 11-18. [CrossRef]

30. Savaget, P.; Geissdoerfer, M.; Kharrazi, A.; Evans, S. The Theoretical Foundations of Sociotechnical Systems Change for Sustainability: A Systematic Literature Review. J. Clean. Prod. 2019, 206, 878-892. [CrossRef]

31. Bhimani, H.; Mention, A.-L.; Barlatier, P.-J. Social Media and Innovation: A Systematic Literature Review and Future Research Directions. Technol. Forecast. Soc. Chang. 2018, 144, 251-269. [CrossRef]

32. Theisen, C.; Munaiah, N.; Al-Zyoud, M.; Carver, J.C.; Meneely, A.; Williams, L. Attack Surface Definitions: A Systematic Literature Review. Inf. Softw. Technol. 2018, 104, 94-103. [CrossRef] 
33. Gupta, S.; Rajiah, P.; Middlebrooks, E.H.; Baruah, D.; Carter, B.W.; Burton, K.R.; Chatterjee, A.R.; Miller, M.M. Systematic Review of the Literature: Best Practices. Acad. Radiol. 2018, 25, 1481-1490. [CrossRef]

34. Polater, A. Managing Airports in Non-Aviation Related Disasters: A Systematic Literature Review. Int. J. Disaster Risk Reduct. 2018, 31, 367-380. [CrossRef]

35. Ruhlandt, R.W.S. The Governance of Smart Cities: A Systematic Literature Review. Cities 2018, 81, 1-23. [CrossRef]

36. Kitchenham, B.; Charters, S. Procedures for Performing Systematic Literature Reviews in Software Engineering; Keele University: Newcastle-under-Lyme, UK; Durham University: Durham, UK, 2007.

37. Page, M.J.; McKenzie, J.E.; Bossuyt, P.M.; Boutron, I.; Hoffmann, T.C.; Mulrow, C.D.; Shamseer, L.; Tetzlaff, J.M.; Akl, E.A.; Brennan, S.E.; et al. The PRISMA 2020 statement: An updated guideline for reporting systematic reviews. BMJ 2021, $29,372$. [CrossRef]

38. Callon, M.; Courtial, J.-P.; Turner, W.A.; Bauin, S. From Translations to Problematic Networks: An Introduction to Co-Word Analysis. Soc. Sci. Inf. 1983, 22, 191-235. [CrossRef]

39. Hirsch, J.E. An Index to Quantify an Individual's Scientific Research Output. Proc. Natl. Acad. Sci. USA 2005, 102, 16569-16572. [CrossRef] [PubMed]

40. Cocosila, M.; Serenko, A.; Turel, O. Exploring the management information systems discipline: A scientometric study of ICIS, PACIS and ASAC. Scientometrics 2011, 87, 1-16. [CrossRef]

41. Oakleaf, M. Writing Information Literacy Assessment Plans: A Guide to Best Practice. Commun. Inf. Lit. 2009, 3, 80-90. [CrossRef]

42. Cobo, M.J.; López-Herrera, A.G.; Herrera-Viedma, E.; Herrera, F. SciMAT: A new science mapping analysis software tool. J. Am. Soc. Inf. Sci. Technol. 2012, 63, 1609-1630. [CrossRef]

43. Fernández-González, J.M.; Díaz-López, C.; Martín-Pascual, J.; Zamorano, M. Recycling Organic Fraction of Municipal Solid Waste: Systematic Literature Review and Bibliometric Analysis of Research Trends. Sustainability 2020, 12, 4798. [CrossRef]

44. Xie, H.; Zhang, Y.; Duan, K. Evolutionary Overview of Urban Expansion Based on Bibliometric Analysis in Web of Science from 1990 to 2019. Habitat Int. 2020, 95, 102100. [CrossRef]

45. Casado-Aranda, L.A.; Sánchez-Fernández, J.; Viedma-del-Jesús, M.I. Analysis of the Scientific Production of the Effect of COVID-19 on the Environment: A Bibliometric Study. Environ. Res. 2020, 193, 110416. [CrossRef]

46. Díaz-López, C.; Carpio, M.; Martín-Morales, M.; Zamorano, M. Analysis of the Scientific Evolution of Sustainable Building Assessment Methods. Sustain. Cities Soc. 2019, 49, 101610. [CrossRef]

47. David, T.M.; Rizol, P.M.S.R.; Machado, M.A.G.; Buccieri, G.P. Future Research Tendencies for Solar Energy Management Using a Bibliometric Analysis, 2000-2019. Heliyon 2020, 6, e04452. [CrossRef] [PubMed]

48. Aparicio, G.; Iturralde, T.; Maseda, A. Conceptual Structure and Perspectives on Entrepreneurship Education Research: A Bibliometric Review. Eur. Res. Manag. Bus. Econ. 2019, 25, 105-113. [CrossRef]

49. Santana, M.; Cobo, M.J. What Is the Future of Work? A Science Mapping Analysis. Eur. Manag. J. 2020, 38, 846-862. [CrossRef]

50. López-Robles, J.R.; Rodríguez-Salvador, M.; Gamboa-Rosales, N.K.; Ramirez-Rosales, S.; Cobo, M.J. The Last Five Years of Big Data Research in Economics, Econometrics and Finance: Identification and Conceptual Analysis. In Proceedings of the Procedia Computer Science; Elsevier, 2019; Volume 162, pp. 729-736. Available online: https:/ /www.sciencedirect.com/science/article/pii/ S1877050919320551 (accessed on 15 August 2021).

51. Kipper, L.M.; Iepsen, S.; Dal Forno, A.J.; Frozza, R.; Furstenau, L.; Agnes, J.; Cossul, D. Scientific Mapping to Identify Competencies Required by Industry 4.0. Technol. Soc. 2021, 64, 101454. [CrossRef]

52. Sharifi, A. Urban Sustainability Assessment: An Overview and Bibliometric Analysis. Ecol. Indic. 2020, 121, 107102. [CrossRef]

53. Carpio, M.; González, Á.; González, M.; Verichev, K. Influence of Pavements on the Urban Heat Island Phenomenon: A Scientific Evolution Analysis. Energy Build. 2020, 226, 110379. [CrossRef]

54. Jebari, C.; Herrera-Viedma, E.; Cobo, M.J. The use of citation context to detect the evolution of research topics: A large-scale analysis. Scientometrics 2021, 126, 2971-2989. [CrossRef]

55. Coulter, N.; Monarch, I.; Konda, S. Software Engineering as Seen through Its Research Literature: A Study in Co-Word Analysis. J. Am. Soc. Inf. Sci. 1998, 49, 1206-1223. [CrossRef]

56. Callon, M.; Courtial, J.P.; Laville, F. Co-Word Analysis as a Tool for Describing the Network of Interactions between Basic and Technological Research: The Case of Polymer Chemsitry. Scientometrics 1991, 22, 155-205. [CrossRef]

57. Kirchherr, J.; Reike, D.; Hekkert, M. Conceptualizing the Circular Economy: An Analysis of 114 Definitions. Resour. Conserv. Recycl. 2017, 127, 221-232. [CrossRef]

58. Cobo, M.J.; López-Herrera, A.G.; Herrera-Viedma, E.; Herrera, F. An Approach for Detecting, Quantifying, and Visualizing the Evolution of a Research Field: A Practical Application to the Fuzzy Sets Theory Field. J. Informetr. 2011, 5, 146-166. [CrossRef]

59. Alcaide-Muñoz, L.; Rodríguez-Bolívar, M.P.; Cobo, M.J.; Herrera-Viedma, E. Analysing the Scientific Evolution of E-Government Using a Science Mapping Approach. Gov. Inf. Q. 2017, 34, 545-555. [CrossRef]

60. Lewandowski, M. Designing the Business Models for Circular Economy-towards the Conceptual Framework. Sustainability 2016, 8, 43. [CrossRef]

61. Sauvé, S.; Bernard, S.; Sloan, P. Environmental Sciences, Sustainable Development and Circular Economy: Alternative Concepts for Trans-Disciplinary Research. Environ. Dev. 2016, 17, 48-56. [CrossRef]

62. Mercader-Moyano, P.; Porras-Pereira, P.; Levinton, C. Circular Economy and Regenerative Sustainability in Emergency Housing: Eco-Efficient Prototype Design for Subaşi Refugee Camp in Turkey. Sustainability 2021, 13, 8100. [CrossRef] 
63. Blomsma, F.; Brennan, G. The Emergence of Circular Economy: A New Framing around Prolonging Resource Productivity. J. Ind. Ecol. 2017, 21, 603-614. [CrossRef]

64. Lieder, M.; Rashid, A. Towards Circular Economy Implementation: A Comprehensive Review in Context of Manufacturing Industry. J. Clean. Prod. 2016, 115, 36-51. [CrossRef]

65. McDonough, W. Cradle to Cradle: Remaking the Way We Make Things, 1st ed.; North Point Press: New York, NY, USA, 2002.

66. Vidyasekar, B.; Selvan, K.G. Implementation of 3R Principle in Construction and Demolition Waste Management. Int. J. Innov. Technol. Explor. Eng. 2019, 8, 667-672. [CrossRef]

67. Erkman, S. Industrial Ecology: An Historical View. J. Clean. Prod. 1997, 5, 1-10. [CrossRef]

68. Kumar, V.; Vuilliomenet, A. Urban Nature: Does Green Infrastructure Relate to the Cultural and Creative Vitality of European Cities? Sustainability 2021, 13, 8052. [CrossRef]

69. Saavedra, Y.M.B.; Iritani, D.R.; Pavan, A.L.R.; Ometto, A.R. Theoretical Contribution of Industrial Ecology to Circular Economy. J. Clean. Prod. 2018, 170, 1514-1522. [CrossRef]

70. Merli, R.; Preziosi, M.; Acampora, A. How Do Scholars Approach the Circular Economy? A Systematic Literature Review. J. Clean. Prod. 2018, 178, 703-722. [CrossRef]

71. Giraldo Nohra, C.; Pereno, A.; Barbero, S. Systemic Design for Policy-Making: Towards the Next Circular Regions. Sustainability 2020, 12, 4494. [CrossRef]

72. Cha, G.W.; Moon, H.J.; Kim, Y.C.; Hong, W.H.; Jeon, G.Y.; Yoon, Y.R.; Hwang, C.; Hwang, J.H. Evaluating Recycling Potential of Demolition Waste Considering Building Structure Types: A Study in South Korea. J. Clean. Prod. 2020, 256, 120385. [CrossRef]

73. de la Torre Bayo, J.J.; Díaz-López, C.; Rodríguez González, M.L.; Ibarra, E.M.; Zamorano, M. Climate classification and its applicability to buildings. WIT Trans. Ecol. Environ. 2019, 238, 311-318.

74. Geng, Y.; Chen, W.; Liu, Z.; Chiu, A.S.F.; Han, W.; Liu, Z.; Zhong, S.; Qian, Y.; You, W.; Cui, X. A Bibliometric Review: Energy Consumption and Greenhouse Gas Emissions in the Residential Sector. J. Clean. Prod. 2017, 159, 301-316. [CrossRef]

75. Murray, A.; Skene, K.; Haynes, K. The Circular Economy: An Interdisciplinary Exploration of the Concept and Application in a Global Context. J. Bus. Ethics 2017, 140, 369-380. [CrossRef]

76. Huang, B.; Wang, X.; Kua, H.; Geng, Y.; Bleischwitz, R.; Ren, J. Construction and Demolition Waste Management in China through the 3R Principle. Resour. Conserv. Recycl. 2018, 129, 36-44. [CrossRef]

77. Jintao, H. Circular Economy Promotion Law; China 2008. Available online: https://www.greengrowthknowledge.org/sites/default/ files / downloads/policy-database/CHINA\%29\%20Circular\%20Economy\%20Promotion\%20Law\%20\%282008\%29.pdf (accessed on 15 August 2021).

78. EUR-Lex-52020DC0098-EN-EUR-Lex. Available online: https://eur-lex.europa.eu/legal-content/EN/TXT/?qid=1583933814 386\&uri=COM:2020:98:FIN (accessed on 2 June 2021).

79. Hopkinson, P.; Chen, H.M.; Zhou, K.; Wang, Y.; Lam, D. Recovery and Reuse of Structural Products from End-of-Life Buildings. Proc. Inst. Civ. Eng. Eng. Sustain. 2018, 172, 119-128. [CrossRef]

80. Andrews, D. The Circular Economy, Design Thinking and Education for Sustainability. Local Econ. 2015, 30, 305-315. [CrossRef]

81. Silva, R.V.; De Brito, J.; Dhir, R.K. Properties and Composition of Recycled Aggregates from Construction and Demolition Waste Suitable for Concrete Production. Constr. Build. Mater. 2014, 65, 201-217. [CrossRef]

82. Meyer, C. The Greening of the Concrete Industry. Cem. Concr. Compos. 2009, 31, 601-605. [CrossRef]

83. Rao, A.; Jha, K.N.; Misra, S. Use of Aggregates from Recycled Construction and Demolition Waste in Concrete. Resour. Conserv. Recycl. 2007, 50, 71-81. [CrossRef]

84. Yuan, H.; Shen, L. Trend of the Research on Construction and Demolition Waste Management. Waste Manag. 2011, 31, 670-679. [CrossRef] [PubMed]

85. Brown, M.T.; Buranakarn, V. Emergy Indices and Ratios for Sustainable Material Cycles and Recycle Options. Resour. Conserv. Recycl. 2003, 38, 1-22. [CrossRef]

86. Kofoworola, O.F.; Gheewala, S.H. Estimation of Construction Waste Generation and Management in Thailand. Waste Manag. 2009, 29, 731-738. [CrossRef]

87. Yeheyis, M.; Hewage, K.; Alam, M.S.; Eskicioglu, C.; Sadiq, R. An Overview of Construction and Demolition Waste Management in Canada: A Lifecycle Analysis Approach to Sustainability. Clean Technol. Environ. Policy 2013, 15, 81-91. [CrossRef]

88. Peng, C.L.; Scorpio, D.E.; Kibert, C.J. Strategies for Successful Construction and Demolition Waste Recycling Operations. Constr. Manag. Econ. 1997, 15, 49-58. [CrossRef]

89. Kartam, N.; Al-Mutairi, N.; Al-Ghusain, I.; Al-Humoud, J. Environmental Management of Construction and Demolition Waste in Kuwait. Waste Manag. 2004, 24, 1049-1059. [CrossRef] [PubMed]

90. Bravo, M.; De Brito, J.; Pontes, J.; Evangelista, L. Mechanical Performance of Concrete Made with Aggregates from Construction and Demolition Waste Recycling Plants. J. Clean. Prod. 2015, 99, 59-74. [CrossRef]

91. Zhao, W.; Leeftink, R.B.; Rotter, V.S. Evaluation of the Economic Feasibility for the Recycling of Construction and Demolition Waste in China-The Case of Chongqing. Resour. Conserv. Recycl. 2010, 54, 377-389. [CrossRef]

92. Del Río Merino, M.; Gracia, P.I.; Azevedo, I.S.W. Sustainable Construction: Construction and Demolition Waste Reconsidered. Waste Manag. Res. 2010, 28, 118-129. [CrossRef]

93. Calvo, N.; Varela-Candamio, L.; Novo-Corti, I. A Dynamic Model for Construction and Demolition (C\&D) Waste Management in Spain: Driving Policies Based on Economic Incentives and Tax Penalties. Sustainability 2014, 6, 416-435. [CrossRef] 
94. De Schepper, M.; Van den Heede, P.; Van Driessche, I.; De Belie, N. Life Cycle Assessment of Completely Recyclable Concrete. Materials 2014, 7, 6010-6027. [CrossRef]

95. Silva, J.; de Brito, J.; Veiga, R. Recycled Red-Clay Ceramic Construction and Demolition Waste for Mortars Production. J. Mater. Civ. Eng. 2010, 22, 236-244. [CrossRef]

96. Liu, J.; Liu, Y.; Wang, X. An Environmental Assessment Model of Construction and Demolition Waste Based on System Dynamics: A Case Study in Guangzhou. Environ. Sci. Pollut. Res. 2020, 27, 37237-37259. [CrossRef]

97. Tam, V.W.Y.; Soomro, M.; Evangelista, A.C.J. A Review of Recycled Aggregate in Concrete Applications (2000-2017). Constr. Build. Mater. 2018, 172, 272-292. [CrossRef]

98. Ledesma, E.F.; Jiménez, J.R.; Ayuso, J.; Fernández, J.M.; De Brito, J. Maximum Feasible Use of Recycled Sand from Construction and Demolition Waste for Eco-Mortar Production-Part-I: Ceramic Masonry Waste. J. Clean. Prod. 2015, 87, 692-706. [CrossRef]

99. Zheng, L.; Wu, H.; Zhang, H.; Duan, H.; Wang, J.; Jiang, W.; Dong, B.; Liu, G.; Zuo, J.; Song, Q. Characterizing the Generation and Flows of Construction and Demolition Waste in China. Constr. Build. Mater. 2017, 136, 405-413. [CrossRef] 